\title{
Suggestions on setting up BIM course in architecture major of colleges and Universities
}

\author{
Yanwei $\operatorname{li}^{1}$ \\ ${ }^{1}$ School of Civil Engineering and Architecture, University of Jinan, Jinan 250022, China
}

\begin{abstract}
Architecture plays an important role in the process of urban construction and social and economic development. Similarly, the application of BIM Technology in the process of urban construction also has a very important significance. To promote the integration of architecture teaching and BIM Technology is not only the need of Architecture Teaching Reform in Colleges and universities, but also the need of urban construction and social and economic development. It is an effective way to promote the development and improvement of the teaching level of architecture major in Colleges and universities to make clear the problems faced by the integration of BIM Technology into the teaching of architecture major in Colleges and universities at the present stage, and take effective measures to establish the teaching mode of architecture major based on BIM technology.
\end{abstract}

\section{Introduction}

BIM Technology, namely building information model, is developed on the basis of modern computer technology. It's an emerging technology. This technology greatly improves the efficiency of the construction industry. It is the inevitable product of the development of information technology in the construction industry, and is a new skill that the construction industry practitioners must master in the future. In recent years, more and more attention has been paid to the application of BIM Technology in China. Based on this, BIM Technology should also be organically integrated into the teaching of architecture major in Chinese colleges and universities, so as to cultivate professional and high-quality talents to meet the requirements of construction industry and national development. This is of great significance to the realization of the ultimate goal of talent cultivation in Colleges and universities.

\section{Characteristics of BIM Technology}

Building information model (BIM) is mainly to collect the relevant data and information of construction engineering, and then use these information to build the building model. Computer technology uses the built building model to analyze various data of construction engineering. At this stage, BIM Technology has been widely used in the construction industry.

According to the research, the main characteristics of BIM Technology include the following aspects. The first feature is visualization. In the process of building engineering construction, people can use BIM Technology to transform engineering related data into 3D models. Through this model, the spatial structure of the building can be fully displayed. What we see is what we can finally get, which is visualization. The second feature is coordination. In the construction process, the design unit, the construction unit and the owner unit should do a good job of coordination, in order to ensure the smooth development of construction. The coordination function of BIM is used to coordinate the problems in construction in advance, and then generate coordination data, which can effectively reduce the occurrence of change problems and improve management efficiency. The third feature is simulation. The staff use BIM Technology to carry out energysaving simulation experiment, emergency evacuation simulation experiment and sunshine simulation experiment in the design stage, which can help the construction unit to identify the key points of construction. At the same time, the staff can also apply BIM Technology to implement 4D simulation, that is to simulate the actual construction process based on the construction scheme, so as to test the scientificity and feasibility of the construction scheme. The fourth feature is optimization. The whole process of planning, design, construction and operation of construction engineering is also a process of continuous optimization. Through the effective application of BIM Technology, people can better carry out optimization. The whole optimization process is largely affected by time, information and complexity. Without effective information, people can not get the expected optimization effect. ${ }^{[1]}$ Through the establishment of BIM model, the model contains the rule information, geometric information and physical information of the building, which provides a good support for the optimization of complex construction projects. 


\section{The necessity of offering BIM course in architecture teaching in Colleges and Universities}

\subsection{BIM Technology plays a significant role in the construction industry}

BIM Technology has been developed rapidly in the world for more than ten years. At present, it has been widely used and recognized. Experts in the construction industry have always stressed the construction life cycle management. Its meaning is to integrate and summarize all kinds of building information in 3D model information database by using BIM Technology, so as to realize collaborative management for architectural designers, construction companies, building owners and facility operators, so as to improve work efficiency, reduce costs and save resources. Building 3D information model is the core of BIM Technology. Through the three-dimensional information model, BIM Technology and digital technology are organically combined to establish an information base consistent with the actual situation, covering the state information, professional attributes, geometric information of buildings, as well as the motion behavior and space state information of unstructured objects. This whole process and all-round $3 \mathrm{D}$ model can improve the integration degree of construction engineering informatization, and provide effective information sharing, information exchange and adjustment platform for the stakeholders of construction engineering. ${ }^{[2]}$

\subsection{Requirements of educational reform in Colleges and Universities}

Nowadays, great changes have taken place in the requirements of the state and Society for talents, and the process of higher education reform is accelerating. Architecture is a practical subject. In addition to academic certificate, skill qualification certificate is also required for students. BIM certificate is one of the necessary skill level certificates for architecture graduates. Based on this reason, in the teaching of architecture major in Colleges and universities, we must integrate BIM Technology organically to improve the application level of students' BIM Technology effectively, so as to cultivate professional and highquality construction talents for the country and society. At the same time, it can also provide a good human resource guarantee for promoting the deep application of BIM Technology in the construction industry. It can be seen that the integration of BIM Technology into architecture teaching in Colleges and universities is the inevitable trend of education and teaching reform in Colleges and universities.

\subsection{Adapt to the demand of construction industry development for talents}

At present, BIM Technology has been widely used in the construction industry, which promotes the information construction and development of the construction industry. In order to promote the development of BIM Technology, Chinese management departments have taken many measures. In 2017, the Ministry of housing and urban rural security of the people's Republic of China required all provinces and cities to speed up the promotion and application of BIM Technology, promote the effective application of BIM Technology in construction projects and urban rail transit projects, and require the first-class and super class construction enterprises, class a survey units and design units in the construction industry to complete the integrated design of BIM information system and other information technologies by the end of 2020. At the same time, BIM Technology is required to account for more than $90 \%$ in the survey stage, design stage, construction stage and operation and maintenance stage of new construction projects. In addition, the application of BIM Technology in green building project assessment is also an important indicator. Due to the short development and application time of BIM Technology, there is a lack of BIM Technology professionals in China. In order to meet the needs of the construction industry for professional talents and promote the sustainable and healthy development of the construction industry, we must integrate BIM Technology into the teaching of construction specialty in Colleges and universities to cultivate professional and technical talents.

\section{Problems of BIM Technology in architecture teaching in Colleges and Universities}

\subsection{Some colleges and universities lack correct understanding and attention to BIM Technology}

At this stage, some colleges and universities do not correctly recognize the important role of BIM Technology and the necessity of integrating BIM Technology into teaching. They simply regard BIM Technology as a software tool or a technical means, which leads to the lack of planning, systematic and practical teaching of BIM Technology. This affects the teaching efficiency and quality of BIM Technology, and leads to the failure to cultivate professional talents skilled in BIM Technology for the society.

\subsection{Some colleges and universities have not set up special BIM courses}

Due to the lack of correct understanding and attention to BIM Technology, many colleges and universities have not set up special BIM courses. Some colleges and universities only carry out BIM Technology lectures in 
the second classroom, and give a general explanation of the relevant content of BIM Technology. Some colleges and universities only carry out BIM primary modeling training courses in concentrated week to improve students' application ability of basic BIM Technology skills. Some colleges and universities have not introduced BIM Technology related content, which leads to students unable to learn BIM Technology related knowledge. Due to the lack of professional BIM courses, it is difficult for students to systematically learn the theoretical knowledge and practical skills of BIM Technology. ${ }^{[3]}$

\subsection{Some colleges and universities lack teaching resources about BIM Technology}

Similarly, due to the lack of correct understanding and attention to BIM Technology, many colleges and universities do not have enough guarantee measures for BIM Technology teaching, which can not provide enough teaching resources for theoretical teaching and practical teaching of BIM Technology. This is mainly reflected in the following aspects. First, there are relatively few systematic and professional BIM Technology textbooks for higher education. Second, some colleges and universities can not guarantee the completeness and effectiveness of relevant teaching facilities. Third, some colleges and universities lack professional teachers. Fourth, some professional teachers lack the research on BIM Technology, do not pay attention to improving their professional skills, and are divorced from the actual situation of the industry and enterprises for a long time, and do not have a clear understanding of enterprise talent demand and industry development situation. As a result, they can not effectively carry out BIM Technology related teaching, which is not conducive to the cultivation of professional BIM Technology talents.

\section{Some suggestions on the integration of BIM Technology into architecture teaching in Colleges and Universities}

\subsection{Some colleges and universities need to change their teaching concepts}

In order to realize the organic integration of BIM Technology into the teaching of architecture major in Colleges and universities, some colleges and universities should change their teaching concepts and improve the correct understanding and attention of BIM Technology. We should actively strengthen the publicity of BIM Technology, achieve effective docking with the construction industry and enterprises, strengthen the research of BIM technology content teaching, and constantly improve the proportion of BIM Technology related content in architecture curriculum. At the same time, we should also do a good job in tracking and guiding the employment of graduates, and actively carry out the evaluation of BIM Technology teaching results, so that we can understand the teaching effect and improve the teaching content in the future.

\subsection{Colleges and universities should set up BIM courses in a planned way}

Under the current situation, colleges and universities should establish a good communication relationship with enterprises, and deeply analyze the application status and trend of BIM Technology in the field of architecture, which is conducive to the design of talent training objectives for colleges and universities. Based on the guidance of talent training objectives, colleges and universities should establish scientific BIM Technology professional training standards, establish enterprise demand-oriented talent training mode, and actively carry out BIM Technology practice teaching. ${ }^{[4]}$ Taking BIM Technology practice teaching as an example, in order to enrich the teaching design, we can let students apply BIM Technology to complete $2 \sim 3$ digital models of complex structure buildings, so as to effectively improve students' practical ability.

\subsection{Some colleges and universities should strengthen the construction of teaching staff}

In the process of integrating BIM Technology into architecture teaching in Colleges and universities, in order to improve the teaching effect of BIM Technology, colleges and universities should strengthen the training of teachers. First of all, according to the professional needs of architecture and BIM technical requirements, colleges and universities should send main teachers to participate in BIM Technology related training, to improve their understanding of BIM Technology and application ability, teaching ability. Secondly, colleges and universities can set up BIM Technology research group, in order to further study BIM Technology and promote teachers to integrate BIM Technology in the teaching process.

\subsection{School enterprise cooperation}

With the help of a project, colleges and universities can carry out school enterprise cooperation to provide students with practical opportunities and improve the quality of BIM Technology teaching. Through practice, students can improve their understanding of the practical application of BIM Technology and job requirements. ${ }^{[5]}$

\section{Conclusion}

To sum up, based on the advantages of BIM Technology, colleges and universities should integrate BIM Technology into the teaching of architecture in order to meet the requirements of education and teaching reform in Colleges and universities and the demand for talents in the construction industry. We need to carefully analyze the problems faced by BIM Technology in teaching, 
starting from changing teaching concepts, setting up BIM courses, strengthening the construction of teaching staff, and carrying out school enterprise cooperation, so as to effectively realize the use of BIM Technology in the teaching of architecture major in Colleges and universities, and promote professional development.

\section{Author introduction:}

Yanwei Li Male. birth date: January, 1978. Title: Lecturer. Work units: University of Jinan. Unit location: Nanxin Zhuang West Road, Jinan City, Shandong Province, China No. 336. zip: 250022.

Tel: 18678870328. E-MAIL: 29387263@qq.com.

Address: School of Civil Engineering and Architecture, University of Jinan, Ji'nan City, Shandong province nanxinzhuang Road No. 336, zip code: 250022

\section{References}

1. Wang Wenli, Chen Hongwei, Shen Guohua. Curriculum system construction of Port Engineering Technology Specialty in Higher Vocational Colleges integrating BIM Technology [J]. Journal of Wuhan communications vocational college, 2019,21 (01): 78-82.

2. Xiong Yujing, Yan Weimin. Research on the application of BIM Technology in College Engineering Teaching [J]. Housing and real estate, 2019 (06): 277.

3. Li Junwei, Cai Baiyan. Optimization of curriculum system of civil engineering and architecture under the guidance of BIM Technology [J]. Education observation, 2019,8 (04): 75-78.

4. Li Yifan, Duan Xusheng, Li Yunteng, Tian Hongchen. Research on the teaching method of BIM Technology integrated into civil engineering specialty [J]. Education modernization, 2018,5 (31): 24-26.

5. Tang biqiu, Chen Yi, Han Jia. Construction of BIM based practice teaching system for civil engineering majors [J]. Education modernization, 2018,5 (23): 164-166. 